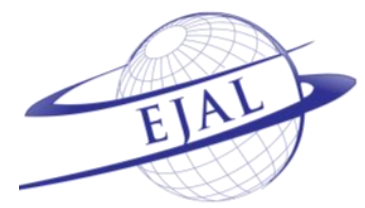

\title{
A Proverb Learned is a Proverb Earned: Proverb Instruction in EFL Classrooms
}

\author{
Nilüfer Can Daşkın ${ }^{a} *$ (D), Çiler Hatipoğlu $b^{\dagger}$ (D)

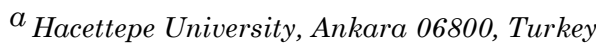

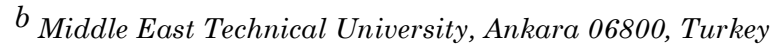

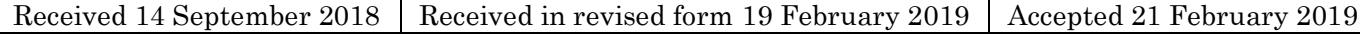

APA Citation:

Can-Daşkın, N., \& Hatipoğlu, Ç. (2019). A proverb earned: proverb instruction in EFL classrooms. Eurasion Journal of Applied Linguistics, 5(1), 57-88. Doi: 10.32601/ejal.543781
\end{abstract}

\begin{abstract}
This study aims to reveal the situation about proverb instruction in EFL classrooms by seeking future English teachers' opinions. It is based on the argument that proverbs are an important part of cultural references, figurative, functional and formulaic language; thereby, they lend themselves well to enhancing communicative competence. This study investigates what EFL student-teachers think and feel about English proverb instruction, how they conceptualize proverbs, how they define their knowledge and use of English proverbs, and what they think about the extent to which their English teachers and coursebooks at high school taught English proverbs. In doing so, a questionnaire was designed and administered to freshman EFL student-teachers and semi-structured interviews were conducted with volunteers. The findings revealed that despite those student-teachers' positive attitudes towards proverb instruction, they did not view their knowledge of English proverbs as well as the teaching of proverbs by their English teachers and coursebooks at high school sufficient enough. Furthermore, traditional definitions were reflected in the participants' conceptualization of proverbs. The study has important implications for curriculum and syllabus design in which knowledge of phraseology in general and proverbs in particular should be incorporated as an important component of learners' language competence.

(C) 2019 EJAL \& the Authors. Published by Eurasian Journal of Applied Linguistics (EJAL). This is an open-access article distributed under the terms and conditions of the Creative Commons Attribution license (CC BY-NC-ND) (http://creativecommons.org/licenses/by-nc-nd/4.0/).

Keywords: Proverb instruction, phraseology, communicative competence, EFL student-teachers
\end{abstract}

\section{Introduction}

Phrasemes are expressions which first become conventionalized and then are reproduced as a "prefabricated unit of language" in discourse (Dobrovol'skij \& Piirainen, 2005, p. 31). Research in the field (especially recent corpus-based studies) demonstrates the high frequency with which these phraseological units are utilized in natural language by native speakers of English (Ellis, 2008). Proverbs are among the communicative phrasemes which are used to express attitudes or feelings towards a propositional content and to affect the interlocutors (Granger \& Paquot, 2008). The

\footnotetext{
* Corresponding author.

E-mail address: can_nilufer@yahoo.com

† ciler@metu.edu.tr
} 
proverbial repertoire of the language is also constantly renewed and modified to better reflect the current contexts more successfully. As Hernadi and Steen (1999) acknowledge, there is no one single culture whether in the past or in the present that "is reported to have gone without them [proverbs]" (p.2).

Since proverbs have many and diverse essential aspects (Taylor, 1931), various schools of thought defined them differently (see D'Angelo, 1977; Dundes, 1975; Harnish, 1993; Milner, 1971; Mieder, 2004; Norrick, 1985; Ulusoy Aranyosi, 2010); but in this study, due to its aims and scope, the definition proposed by Mieder (2004), which is more inclusive and empirically derived has been adopted:

A short, generally known sentence of the folk which contains wisdom, truth, morals, and traditional views in a metaphorical, fixed and memorisable form and which is handed down from generation to generation. (p.3)

Considering Bachman's model of communicative competence (1990) which consists of organizational (i.e., grammatical and textual competence) and pragmatic competence (i.e., illocutionary and sociolinguistic competence), proverbs can be incorporated in language classrooms to contribute to the development of each subcompetence all of which eventually constructs communicative competence. This argument is based on Littlemore and Low's discussion (2006a, 2006b) that the role of figurative language, particularly metaphors goes beyond the ability to interpret cultural references and figures of speech as they constitute an important part of each component in Bachman's framework. The same argument holds true for proverbs, which are an important part of such figurative language, because "proverbs and the metaphors contained in them comprise a microcosm of what it means to know a second language". That is, proverbs require the knowledge of not only the linguistic structure but also the sociolinguistic and discourse factors that are necessary to recognize and use them appropriately. (Nuessel, 2003, p.158).

To start with those aspects of proverbs that can be deployed to contribute to the development of sociolinguistic competence, proverbs are an important part of cultural references and figures of speech, which require an ability to interpret them as constitutive of one's sociolinguistic competence. Proverbs are cultural references because they are traditional and a part of cultural literacy that expresses the shared knowledge, experiences, values, history and thoughts of a nation (Alkaya, 2001; Hirsch, Kett, \& Trefil, 2002; Mieder, 2007). The study of proverbs can, therefore, help to improve cultural and intercultural competence by allowing learners to gain insights into how native speakers conceptualize experiences, things and events in their language (Al-Issa, 2005; Bessmertnyi, 1994; Ciccarelli, 1996; Richmond, 1987; Yano, 1998). As part of figurative language, many proverbs are metaphorical and contain prosodic devices (D’Angelo, 1977; Lakoff \& Turner, 1989; Mieder, 2004; Norrick, 1985; Ridout \& Witting, 1969), which means that they can be used to prompt figurative thinking and enhance metaphoric competence (Littlemore \& Low, 2006a). On the other hand, as part of formulaic language, the use of proverbs can enable fluent and natural language production (i.e., sensitivity to naturalness), which is another 
component of sociolinguistic competence (Sinclair, 1992; Prodromou, 2003; Wray, 2000; Yorio, 1980). Even though language learners prefer literal and direct language items to idiomatic expressions (O'Keeffe, McCarthy, \& Carter, 2007), "avoiding the use of idioms gives language a bookish, stilted, unimaginative tone" (Cooper, 1999, p.258). Research also shows that native speakers use proverbs as "a significant rhetorical force in various modes of communication" such as friendly chats, political speeches, best-seller novels and the influential mass media (Mieder, 2004, p.1). Therefore, the teaching of proverbs in relation to their use in different contexts can enhance learners' sensitivity to dialects and registers, which forms another element of sociolinguistic competence. Apart from sociolinguistic competence, proverbs manifest themselves as valuable resources for developing illocutionary competence. Because they may be used to perform many communicative functions especially indirect speech act as a politeness strategy, they are an important part of functional language (Mieder \& Holmes, 2000; Norrick, 2007; Searle, 1975). In sum, teaching the above mentioned aspects of proverbs in context can contribute to the improvement of language learners' illocutionary and sociolinguistic competences and eventually, their pragmatic competence (Charteris-Black, 1995).

As well as the importance of proverbs for pragmatic competence, they also appear as valuable phrasemes for organizational competence that is composed of grammatical and textual competences. For example, they can be used as practical tools for instructional purposes such as teaching vocabulary, exemplifying and practicing grammar points, illustrating the creative use of language, and teaching and practicing pronunciation due to their musical quality (Holden \& Warshaw, 1985; Nuessel, 2003; Yurtbaşı, n.d.). That is, when utilised appropriately, proverbs can pave the way for the improvement of language learners' grammatical competence. Proverbs can also play a role in the development of textual competence since they are powerful rhetorical devices and have salient communicative features whose usage can lead to effective spoken and written communication (McWilliam, 1997; Vanyushkina-Holt, 2005). They are also regularly used by competent writers/speakers in topic transition sequences and/or at the beginning and the end of their text to introduce or summarise an idea (Drew \& Holt, 1998; Irujo, 1986; Littlemore \& Low, 2006a; Obeng, 1996). For these reasons, teaching all the aforementioned aspects of proverbs can improve both organizational and pragmatic competence and eventually communicative competence of learners.

It should also be noted that learning proverbs is not easy without explicit instruction in the language classrooms particularly in EFL settings. It is not always easy to comprehend proverbs as they require background knowledge and familiarity due to their cultural, often figurative and indirect nature. Besides, native speakers do not always use proverbs in their full units, expecting the hearer to identify them as the common knowledge of a society (Bessmertnyi, 1994; Mieder, 2004). For instance, they usually play with the language of proverbs to create humour, irony and jokes (i.e., anti-proverbs) (Litovkina \& Mieder, 2006), which could only be understood if the hearer or the reader knows the proverb. Because of these reasons, proverbs are quite 
difficult to learn without explicit instruction in the EFL classroom. Despite the necessity of explicit instruction on proverbs, proverbs are rarely incorporated in the language classroom and are usually used as "time-fillers" and not studied in context (Litovkina, 2000). Proverb instruction is even more vital for future language teachers. With regard to this, Thomas (1987) points out that since language teachers' goal is to help their learners gain language competence, they "should themselves have language competence to a greater degree than that expected of their learners" (p.34).

\section{Literature review}

The literature is quite vast when considering the studies on a wide range of idiomatic expressions. Therefore, the review here is mostly limited to the literature on proverbs. A great deal of research has been carried out on proverbs in the field of psycholinguistics (e.g., Cruz, 1995; Kemper, 1981; Kowbel, 2005; Nippold, Allen, \& Kirsch, 2001; Temple \& Honeck, 1999; Turner, 1995; Vulchanova, Vulchanov, \& Stankova, 2011). Among the few studies on proverbs in foreign language teaching are the ones conducted related to the place of proverbs in textbooks, dictionaries or reference books (Alexander, 1984; Lazar, 2003; Turkol, 2003; Vanyushkina-Holt, 2005). The common finding in these studies is that proverbs constitute a very small part of foreign language teaching materials regardless of the language being taught. Lazar's (2003) findings seem to include a few exceptions in that the book (i.e., Mirrors and Windows) he introduced is an intercultural communication textbook that includes examples of proverbs as well as idioms and sayings from various cultures for comparison in the language section of each unit to show the reflection of culture in language. Besides material analysis, a few other studies used questionnaires to examine teachers' or learners' attitudes to proverbs or idiomaticity. To illustrate, administering a questionnaire to the teachers, Hanzen (2007) found out that the teachers had a positive attitude towards the use of proverbs in teaching English. Likewise, using two questionnaires, Liontas (2002) investigated second language learners' notion of idiomaticity. Some of his findings are that most of the respondents (1) had not received explicit instruction on idioms despite their strong desire and interest in learning idioms, (2) thought that the idioms should be incorporated as an essential component of their language and culture learning, (3) recognized the important role of idioms in natural and real-life communication, and (4) were not content with their present knowledge of idioms. Different from these studies, Turkol (2003) examined familiarity and interpretation of proverbs by non-native speakers of English and her results revealed that though the subjects' familiarity with the proverbs was lower than expected, their interpretation of these proverbs was quite accurate.

As for those studies conducted in the context of Turkey, Çakır, (2010) examined proverb instruction indirectly by quantitatively analysing the cultural expressions and references such as idioms, proverbs and superstitions in three English coursebooks studied in primary schools in Turkey. He reported that very few cultural elements were included and that proverbs were almost non-existent in these 
coursebooks. Similarly, Arıkan and Tekir (2007) assessed the quality of a local English coursebook used in Turkey for 7th grade by seeking the opinions of teachers and students through questionnaires. As part of their study, the teachers, who had negative feelings about the coursebook, indicated that the coursebook should contain more cultural expressions and vocabulary such as proverbs and idioms. A few other studies offered activities to promote the use of proverbs in developing foreign language skills and to raise awareness of the arbitrary nature of such figurative expressions (Çakır, 2016; Gözpınar, 2014). Other studies in the context of Turkey are concerned particularly with idioms; for example, the frequency of idiom use by foreign language learners (Kaya \& Yilmaz, 2018), analysis of idiom use in instructional materials (Khan \& Can, 2014), idiom processing in L2 (Bulut \& Çelik-Yazıcı, 2004; Elkılıç, 2008) and the pedagogical approaches to teaching idioms (Göçmen, Göçmen, \& Ünsal, 2012).

As can be seen, to the best knowledge of the authors, only a few studies have been conducted about proverb teaching in foreign language classrooms and there is almost no empirical study with respect to proverb instruction particularly in Turkish context. There seems to be a need to go beyond material analysis and the suggestions about the ways of teaching proverbs to what the learners' overall experiences of learning proverbs are. The case of proverb instruction in foreign language instruction needs to be empirically and thoroughly understood from the perspective of learners themselves so that we can uncover their needs and offer suggestions accordingly.

\subsection{Research questions}

This study is expected to contribute to filling an important gap in the literature with respect to the study of proverbs in foreign language education. Keeping this in mind, in general, this study aims to provide a vivid picture of proverb instruction in Turkish EFL classrooms so that stakeholders' awareness can be developed about proverb instruction and some useful suggestions can be made accordingly.

The research questions of this study are:

What are EFL student-teachers'

(1) conceptualization of proverbs?

(2) attitudes towards learning and teaching English proverbs?

(3) thoughts about their knowledge and use of English proverbs?

(4) perceptions about their high-school English teachers' practices in teaching proverbs in the classroom?

(5) perceptions about the sufficiency of the English coursebooks they used at high school in dealing with proverbs? 


\section{Method}

\subsection{Participants}

In this study, EFL student-teachers' opinions were sought in order to reveal the situation about teaching proverbs in English language classrooms. In total, 187 student-teachers studying in English Language Teaching Departments (ELT) in some of the top universities in Turkey filled in the questionnaires. As students of English, who were going to become English teachers, they were assumed to have gained a high level of proficiency in English. The aim was, thus, to see if they had received sufficient proverb instruction in their language classrooms at high school. Of these participants, only the students who were in their first year at their university were particularly selected because it was thought that as new graduates of high school, it would be easier for them to remember their experiences back in high school. Therefore, the sample consisted of students who directly started their first-year at the ELT Department without being required to attend the English preparatory school and thus, those students who had attended a year-long English preparatory program before starting their departments were excluded from the study. In a similar vein, the sample also included those studying in preparatory school in their first year at the funiversity, excluding those who were repeating their preparatory classes. At the time of the data collection procedure, 72 of the participants (38.5\%) were preparatory school students while 115 (61.5\%) were freshmen in the Departments of ELT in three public universities in Ankara. The latter group of students were allowed to move to their departments since they had taken and passed the English proficiency exam administered at the beginning of the academic year. Regarding the gender of the participants, the majority of the participants were female with $78.1 \%$ while the remaining $21.9 \%$ were male. The high number of female students reflects the gender distribution at the Faculties of Education in Turkey.

\subsection{Instrument and analysis}

A questionnaire was designed to find answers to the research questions. The studies that were taken as the springboard were Hanzen (2007), Turkol (2003) and Liontas (2002).

The questionnaire was designed in several stages. In the first stage, an item pool was created based on the literature review and then the most vital and relevant items $(\mathrm{N}=80)$ were chosen in line with the specific research questions. As suggested by Dörnyei (2003), the items that deal with the same topic were categorized to have a systematic and clear structure. In doing so, four sub-sections were constructed based on the research questions. Apart from these, Likert scale was used as the most commonly employed scaling technique due to its simplicity, versatility, and reliability (Dörnyei, 2003, p.36). Besides, sections related to the background and foreign language learning experiences of the participants were also added to the questionnaire to get some demographic information about the participants. 
In ordering the subsections, order effects, in particular the consistency and redundancy effects (Foddy, 1993; Schuman \& Presser, 1996) were taken into consideration. The items in each section were grouped from general to more specific to eliminate order effects. For example, the section on participants' attitudes towards learning and teaching proverbs precedes the other sections so that their attitudes were revealed without any influence of the other sections which are more factual and behavioural. Additionally, the items on participants' thoughts about their knowledge of proverbs appears before the items asking about their experiences of learning proverbs at high school to reduce consistency effects. For example, if a respondent reflects on his/her experiences of learning proverbs at high school in the first place, and indicates that his/her teachers and coursebooks did not deal with English proverbs sufficiently, then when responding to items about his/her proverb knowledge, s/he might have the tendency to express lack of competence in proverbs in an attempt to appear consistent.

In the second stage, the questionnaire underwent an initial piloting with four experts to ensure high reliability and validity. Making the necessary changes based on the results of the initial piloting, the questionnaire was improved and prepared for final piloting in the third stage. For final piloting, the questionnaire was administered to a representative group of 23 first-year students in the ELT Department in one of the top universities. In line with the feedback obtained from them, the necessary amendments and improvements were made in the questionnaire.

Finally, internal consistency for the whole questionnaire was found to be highly reliable with a Cronbach's Alpha coefficient of 0.94. However, despite the high Cronbach's Alpha coefficient, those items which generated corrected item-total correlation of less than 0.3 were further examined. In doing this, an interview was carried out with four volunteers, who were selected from among the ones having completed the questionnaire previously and who were asked questions about these items. It was seen that the items which the participants found too general, ambiguous or abstract had low correlation and thereby, they were transformed into more concrete and specific items. To illustrate, the item that stated "I know what a proverb is" was decided to be turned into an open-ended question asking the participants to briefly define what a proverb is. Consequently, some improvements were made on these items.

Having undergone all these processes, the questionnaire was eventually finalized and prepared for actual administration. After all the changes, it had a total of 77 items with other open-ended questions (See Appendix A). Part A consisted of an openended question that asked about the participants' definition of a proverb. Part B was composed of items regarding the participants' attitudes towards proverb instruction (items 1-20). Items 21-35 constituted part $\mathrm{C}$ on their knowledge of proverbs. Lastly, part D was designed to investigate their experience of learning English proverbs at high-school with items 36-77 preceded by an open-ended question about the materials their teachers had used to teach proverbs. 
In analysing the questionnaires, descriptive statistics was used. While discussing the results, for each item, the degree of (dis)agreement was calculated by adding percentages from the 'strongly (dis)agree' and '(dis)agree' categories to "ascertain an overall indication of disagreement and agreement" and thus, to yield a general picture of the results (Cohen, Manion, \& Morrison, 2007, p. 510). The open-ended question soliciting for a proverb definition was analysed using the "Computerized Language Analysis Child Language Data Exchange System” (CLAN CHILDES).

In order to triangulate the data, a semi-structured interview was conducted with those participants $(\mathrm{N}=21)$ who had given their consent to participate in the interview after completing the questionnaire. Depending on the participants' consent, the interviews were audio-recorded and/or video-recorded. The interview questions were formulated with reference to the items in the questionnaire and piloted several times. In analysing the interviews, the audio and/or video recordings of twenty-one interviews were transcribed by means of a transcription software and the transcriptions were coded for recurring themes and analysed by employing inductive data analysis method (Mackey \& Gass, 2005).

\section{Results and discussion}

\subsection{What are EFL student-teachers' conceptualization of proverbs?}

Student-teachers were asked to write their definitions of what a proverb is so as to reveal their understanding of a proverb. Of the 187 participants, 157 could define a proverb or list key words that they associated with proverbs. The key words that most commonly appeared in the data were identified and coded into categories (See Appendix B).

The findings show that in their definitions, the participants mostly referred to the cultural aspects of proverbs. For example, they most frequently associated proverbs with the old times (55\%). The long history of proverbs makes them anonymous and this was the third most commonly indicated aspect of proverbs in the definitions (22.3\%). The definitions point out that the experiences of the folk throughout a society's history have led to the emergence of proverbs. Apart from the cultural aspects of proverbs, the participants also referred to some of their formal aspects in the definitions. The fixed form of proverbs was, for instance, the second most frequent characteristic included in the definitions. As for the pragmatic features of proverbs, the didactic and guiding functions of proverbs appeared in $17.2 \%$ of the definitions. Finally, of the literary features of proverbs, the metaphorical nature of proverbs was the frequently stated literary aspect (16.6\%).

Overall, it can be seen that the participants' definitions mostly included some of the cultural and formal aspects of proverbs. Due to the variety in the forms of proverbs, there is not an exact and inclusive definition that can enable one to identify them with any certainty. The features indicated in the definitions are not necessarily a part of every proverb nor are the other features apparent in some proverbs a part of the 
available definitions. The definitions show that the participants had traditional views of proverbs. The instruction they had received at school especially in their Turkish language classes might have affected their conceptualization of proverbs. In the Turkish context, students are expected to possess a proverb dictionary since primary school and to know what proverbs are. Therefore, they are exposed to some standard definitions of proverbs one of which is given below:

Proverbs are sentences that were produced based on long-term experiences and observations and have become fixed and the property of the folk. A considerable part of proverbs are written in present tense or in imperatives. Proverbs are usually fixed expressions which give advice or message (Eker, 2006, p. 479).

As this definition illustrates, the participants' definitions seem to correspond with such a standard definition. However, many researchers nowadays have questioned these traditional definitions with counter examples of proverbs proving the insufficiency of the traditional definitions (e.g., Norrick, 1985, 2007; Mieder, 2004; Ulusoy Aranyosi, 2010). With the new developments and changes in technology and the nature of communication, proverbs also undergo certain modifications (Ulusoy Aranyosi, 2010), which shows their dynamic nature. Unlike what the participants stated in their definitions, proverbs do always reflect old times and have a fixed form. While some proverbs are forgotten, new ones are created or the old ones are adapted (Litovkina \& Mieder, 2006). Besides, the formation of anti-proverbs, defined as proverb variations (e.g., If at first you don't succeed, give up), provides strong evidence for the dynamic nature of proverbs (Mieder, 2004). In addition to anti-proverbs, the reduced forms of proverbs (i.e., truncated proverbs) are also widely used in everyday communication (Mieder, 2004) which demonstrates that proverbs do not always appear in their fixed forms. Thus, "the fixed form of proverbs does not appear to be as sacrosanct anymore today as it might have once been" (Mieder \& Holmes, 2000, p.90). Furthermore, as opposed to the idea in the traditional definitions that proverbs express general truths, anti-proverbs prove that those truths can be challenged and questioned. Considering these changes in the understanding of proverbs, the proverb definitions presented to the students need to be renewed and updated to provide a more accurate picture of proverbs in modern times. In this respect, it is necessary for the stakeholders to question "the taken-for-granted" definitions of proverbs and adapt them in the light of current research.

\subsection{What are EFL student-teachers' attitudes towards learning and teaching English proverbs?}

To find out EFL student-teachers' attitudes towards learning and teaching English proverbs, they were asked to respond to items 1-20 based on a Likert scale. The majority of the participants (strongly) agreed that learning proverbs is an important part of English language learning experience (item 1, 81.2\%, $M=4.08$ ) and that it is needed for effective communication in the target language (item $2,78.6 \%, M=4.01$ ) (See Table 1). The reasons for why item 2 about the necessity of proverbs for effective 
communication received the highest percentage of agreement can be explained with responses to other items as follows: (1) becoming familiar with the English figurative expressions (item 11,96.3\%, $M=4.54$ ) and using them (item 12, 93.6\%, $M=4.43$ ), (2) making sense of humours in English (item 10, 91.4\%, $M=4.36$ ), (3) perceiving the cultural similarities and differences better (item 9, 90.9\%, $M=4.39$ ) and understanding the target culture (item $8,90.4 \%, M=4.40$ ), and (4) comprehending listening (item $7,90.3 \%, M=4.35$ ) and reading (item $6,89.7 \%, M=4.32$ ) texts more easily. A majority of them found 'learning how to use proverbs' important for developing their speaking skills (item 3, 83.9\%, $M=4.06$ ), for making their speech more effective in oral presentations (item $4,81.2 \%, M=4.07$ ) and for understanding the everyday language better (item $13,83.2 \%, M=4.06$ ), while a relatively lower percentage of the participants considered it essential for improving their writing skills (item $5,69.6 \%, M=3.80$ ).

Table 1. EFL student-teachers' attitudes towards learning and teaching English proverbs

\begin{tabular}{|c|c|c|c|c|c|c|c|c|c|c|c|}
\hline \multirow[b]{2}{*}{ ITEM } & \multicolumn{2}{|c|}{$\begin{array}{l}\text { 1 Strongly } \\
\text { Disagree }\end{array}$} & \multicolumn{2}{|c|}{2 Disagree } & \multicolumn{2}{|c|}{3 Neutral } & \multicolumn{2}{|c|}{4 Agree } & \multicolumn{2}{|c|}{5 Strongly Agree } & \multirow{2}{*}{$\begin{array}{l}\text { Mean } \\
\mathrm{M}\end{array}$} \\
\hline & $\mathrm{N}$ & $\%$ & $\mathrm{~N}$ & $\%$ & $\mathrm{~N}$ & $\%$ & $\mathrm{~N}$ & $\%$ & $\mathrm{~N}$ & $\%$ & \\
\hline 1 & 2 & 1.1 & 7 & 3.8 & 26 & 14.0 & 91 & 48.9 & 60 & 32.3 & 4.08 \\
\hline 2 & 2 & 1.1 & 7 & 3.7 & 31 & 16.6 & 94 & 50.3 & 53 & 28.3 & 4.01 \\
\hline 3 & 3 & 1.6 & 4 & 2.2 & 23 & 12.4 & 104 & 55.9 & 52 & 28.0 & 4.06 \\
\hline 4 & 3 & 1.6 & 5 & 2.7 & 27 & 14.5 & 92 & 49.5 & 59 & 31.7 & 4.07 \\
\hline 5 & 4 & 2.2 & 13 & 7.1 & 39 & 21.2 & 87 & 47.3 & 41 & 22.3 & 3.80 \\
\hline 6 & 2 & 1.1 & 8 & 4.3 & 9 & 4.9 & 76 & 41.3 & 89 & 48.4 & 4.32 \\
\hline 7 & 3 & 1.6 & 5 & 2.7 & 10 & 5.4 & 73 & 39.5 & 94 & 50.8 & 4.35 \\
\hline 8 & 2 & 1.1 & 1 & .5 & 15 & 8.1 & 71 & 38.2 & 97 & 52.2 & 4.40 \\
\hline 9 & 2 & 1.1 & 2 & 1.1 & 13 & 7.0 & 74 & 39.8 & 95 & 51.1 & 4.39 \\
\hline 10 & 3 & 1.6 & 4 & 2.1 & 9 & 4.8 & 78 & 41.7 & 93 & 49.7 & 4.36 \\
\hline 11 & 2 & 1.1 & 0 & .0 & 5 & 2.7 & 68 & 36.4 & 112 & 59.9 & 4.54 \\
\hline 12 & 2 & 1.1 & 2 & 1.1 & 8 & 4.3 & 76 & 40.9 & 98 & 52.7 & 4.43 \\
\hline 13 & 4 & 2.2 & 10 & 5.4 & 17 & 9.2 & 94 & 50.8 & 60 & 32.4 & 4.06 \\
\hline 14 & 7 & 3.7 & 18 & 9.6 & 57 & 30.5 & 80 & 42.8 & 25 & 13.4 & 3.52 \\
\hline 15 & 3 & 1.6 & 13 & 7.0 & 45 & 24.1 & 97 & 51.9 & 29 & 15.5 & 3.73 \\
\hline 16 & 4 & 2.1 & 9 & 4.8 & 27 & 14.4 & 83 & 44.4 & 64 & 34.2 & 4.04 \\
\hline 17 & 6 & 3.2 & 4 & 2.1 & 41 & 21.9 & 89 & 47.6 & 47 & 25.1 & 3.89 \\
\hline 18 & 6 & 3.2 & 3 & 1.6 & 25 & 13.4 & 94 & 50.3 & 59 & 31.6 & 4.05 \\
\hline 19 & 6 & 3.2 & 15 & 8.0 & 36 & 19.3 & 77 & 41.2 & 53 & 28.3 & 3.83 \\
\hline 20 & 3 & 1.6 & 4 & 2.2 & 27 & 14.5 & 93 & 50.0 & 59 & 31.7 & 4.08 \\
\hline
\end{tabular}


Interview results are found to be consistent with the questionnaire data. Of the 21 interviewees, 15 stated clearly that learning English proverbs is important for a wide range of reasons (e.g., for an easy and effective communication). Regarding the participants' need for learning proverbs, one of them said the following:

Because we have very limited knowledge about this topic (proverbs), we can't even make sense of the jokes in our English coursebooks. Not being able to capture their perspectives results in our not being able to learn their culture. This results in obstacles in our learning the language. (S1)

With respect to the necessity of learning proverbs, some of the interviewees have emphasized such a need particularly for those who are planning to go abroad or have jobs that require an active use of English. On the other hand, the other interviewees thought that it was difficult to learn English proverbs in Turkish language education system which focused on teaching grammar and test-taking strategies. Some even considered the learning of English proverbs extra in the early stages of English language education and found it significant and relevant only for advanced levels after students gain some practice with English.

Besides the significance of learning English proverbs, most of the participants thought that it is important to teach proverbs in English classrooms (item 16, 78.6\%, $M=4.04$ ) and to incorporate them in English coursebooks (item 18, 81.9\%, $M=4.05$ ). However, a relatively lower number of the participants thought they would definitely teach English proverbs when they became an English teacher (item 17, 72.7\%, $M=$ 3.89) and that proverbs should take place in the English language curriculum at high school (item 19, 69.5\%, $M=3.83$ ). The interview findings further explain the participants' positive attitudes towards proverb teaching as some of the interviewees who gave importance to proverb teaching $(N=5)$ indicated that they did not want to make the same mistake as their teachers had done and hence commented:

I would definitely teach (proverbs). After coming here (starting university) we realize this, we wish our teacher had focused more on them (proverbs). (S3)

Despite many participants' positive attitudes towards the teaching of English proverbs in the classroom, the percentage of agreement with regard to the necessity of teaching English proverbs is not as high when compared to the necessity of learning them. This can be explained by the interview findings. Though the interviewees all wanted to have some room for proverb instruction in the classroom, when they were asked about how they would teach proverbs, their explanations revealed that they considered proverbs as something additional rather than an integral component of the lessons. To exemplify, they wanted to teach proverbs when an opportunity arose by encountering them in the coursebooks, to assign them as a self-study, write them on the board for peripheral learning or present them as an extra-curricular activity for entertainment purposes. Furthermore, of these interviewees who expressed preference for the teaching of proverbs, four were thinking to allocate only a short time for proverb teaching because they had to give priority to other primary language components and skills. The language education system which prioritized grammar, 
reading skills and test taking strategies might have caused them to regard proverbs as additional. For example, one of the students stated:

Certainly (I would teach proverbs) but I would of course not spare a great deal of the classroom time for this (proverb teaching) but I would certainly want to give place to them, for instance, for an hour a week. (S2)

Additionally, some respondents' neutral attitude towards the teaching of proverbs might be due to their lack of command of English proverbs, which was acknowledged by some of the interviewees, who noted that they themselves needed to learn proverbs to be able to teach them. Based on this, those participants' neutral and negative view about teaching proverbs can be explained by the respondents' definitions, which mostly referred to proverbs as reflecting old times (See Section 4.1) and thus, such an understanding of proverbs might have caused the participants to consider proverbs less worthwhile to teach in modern times.

Overall, the participants adopted a positive attitude towards learning and teaching English proverbs and thought that proverbs would improve their language skills and make their communication easier in many respects. The results in this section seem to be in line with the findings of Liontas's study (2002) where the majority of the learners also expressed a desire and interest in learning idioms as they recognized the importance of idioms for natural and real-life communication and thus, wanted them to be an integral part of their language and culture learning. Moreover, similar to the result in this study that learning proverbs was considered to be important by most of the participants for using figurative language and understanding humours in English, in Turkol's study (2003), too, proverbs were preferred to be used by all the subjects in informal situations for joking and for indirect and practical uses of language. Consequently, the positive results in this section can be encouraging for teachers, material writers and curriculum designers to give place to proverbs in language classrooms.

\subsection{What are EFL student-teachers' thoughts about their knowledge and use of English proverbs?}

Considering the responses to the items regarding EFL student-teachers' thoughts about their knowledge and use of English proverbs, many of the respondents thought that they had no knowledge about the cultural, literary, formal and semantic aspects of English proverbs (See Table 2). The interview results validate the finding that student-teachers (90\%) did not possess much knowledge about English proverbs. When all the 21 interviewees were asked to give examples of English proverbs, 13 of them could not come up with any English proverb. Three of the interviewees confused them with idioms and gave examples such as put someone to sleep and it's raining cats and dogs. The proverbs only a few interviewees could remember $(N=5)$ were - like father like son, what goes around comes around, better late than never, and an apple a day keeps the doctor away- though they did not all appear in the right structure. Nevertheless, the interviewees all expressed their wish to have known more English proverbs. On the other hand, a relatively higher number of the participants agreed 
that they knew in what situations (item 25, 29.9\%, $M=2.94$ ), and for what purposes (item $26,51.4 \%, M=3.35$ ) to use English proverbs, which could have been influenced by their knowledge and use of Turkish proverbs. This is also acknowledged by the interviews in which they could mention a wide range of situations and purposes such as (1) communicating with native speakers better, (2) creating humour, (3) supporting the arguments, and (4) beautifying and embellishing the language.

Table 2. Knowledge of English proverbs

\begin{tabular}{llllllllllll}
\hline \multicolumn{3}{l}{ 1 Strongly } & \multicolumn{2}{l}{ 2 Disagree } & \multicolumn{2}{l}{ 3 Neutral } & \multicolumn{2}{l}{ 4 Agree } & \multicolumn{3}{l}{ 5 Strongly } \\
Agree & & Mean \\
\hline ITEM & $\mathrm{N}$ & $\%$ & $\mathrm{~N}$ & $\%$ & $\mathrm{~N}$ & $\%$ & $\mathrm{~N}$ & $\%$ & $\mathrm{~N}$ & $\%$ & $\mathrm{M}$ \\
\hline 21 & 16 & 8.6 & 66 & 35.3 & 77 & 41.2 & 24 & 12.8 & 4 & 2.1 & 2.65 \\
22 & 21 & 11.3 & 58 & 31.2 & 67 & 36.0 & 40 & 21.5 & 0 & .0 & 2.68 \\
23 & 20 & 10.9 & 77 & 41.8 & 55 & 29.9 & 31 & 16.8 & 1 & .5 & 2.54 \\
24 & 22 & 11.8 & 82 & 44.1 & 54 & 29.0 & 26 & 14.0 & 2 & 1.1 & 2.48 \\
25 & 12 & 6.4 & 49 & 26.2 & 70 & 37.4 & 50 & 26.7 & 6 & 3.2 & 2.94 \\
26 & 6 & 3.2 & 23 & 12.3 & 62 & 33.2 & 91 & 48.7 & 5 & 2.7 & 3.35 \\
27 & 15 & 8.1 & 51 & 27.6 & 90 & 48.6 & 28 & 15.1 & 1 & .5 & 2.72 \\
28 & 11 & 5.9 & 30 & 16.2 & 48 & 25.9 & 90 & 48.6 & 6 & 3.2 & 3.27 \\
29 & 13 & 7.0 & 44 & 23.8 & 69 & 37.3 & 51 & 27.6 & 8 & 4.3 & 2.98 \\
30 & 9 & 4.8 & 12 & 6.5 & 49 & 26.3 & 108 & 58.1 & 8 & 4.3 & 3.51 \\
$31 \neq$ & 42 & 22.6 & 71 & 38.2 & 46 & 24.7 & 22 & 11.8 & 5 & 2.7 & 2.34 \\
32 & 30 & 16.2 & 75 & 40.5 & 49 & 26.5 & 28 & 15.1 & 3 & 1.6 & 2.45 \\
33 & 30 & 16.0 & 76 & 40.6 & 48 & 25.7 & 31 & 16.6 & 2 & 1.1 & 2.46 \\
34 & 45 & 24.1 & 84 & 44.9 & 44 & 23.5 & 13 & 7.0 & 1 & .5 & 2.15 \\
35 & 48 & 25.7 & 93 & 49.7 & 36 & 19.3 & 9 & 4.8 & 1 & .5 & 2.05 \\
\hline
\end{tabular}

Besides their knowledge of English proverbs, more than half of the respondents thought that they could recognize English proverbs in listening (item 28, 51.8\%, $M=$ 3.27) and reading texts (item 30,62.4\%, $M=3.51$ ) even if they did not understand them but fewer of them agreed that they could both recognize and understand English proverbs in listening and reading texts. Compared to the participants' recognition and understanding of English proverbs in listening texts (item 27, 15.6\%, $M=2.72$ ), a greater number of them felt more confident in identifying and understanding them in reading texts (item $29,31.9 \%, M=2.98$ ) (See Table 2 ). In a similar vein, almost two thirds of the participants thought that they had difficulty understanding proverbs in English songs and movies (items 31 and 32). This is an expected outcome considering the fact that a more complex cognitive process is involved in trying to understand a listening text (Vandergrift, 1999). Reading is also a demanding task; however, readers always have the opportunity to go back and forth to read any incomprehensible part over and over again (Lund, 1991). The interview results further verify the finding with respect to the participants' recognition and understanding of English proverbs

\footnotetext{
${ }^{\ddagger}$ Items 31 and 32 are reversed.
} 
since the interviewees have also revealed that they could recognize English proverbs but had difficulty in making sense of them. The interviews have also revealed those aspects of proverbs that helped the participants to identify them. Many of the interviewees (75\%) indicated that it was mainly the metaphorical and fixed nature of proverbs as well as their unusual structure that enabled them to identify the proverbs.

As for the use of English proverbs, the majority of the participants did not consider that they could use proverbs in writing (item $33,56.6 \%, M=2.46$ ) and in speaking (item 34, 69\%, $M=2.15$ ) in English, which are the productive skills (See Table 2). However, compared to the number of the participants who were able to use English proverbs in speaking $(7.5 \%)$, the number of those who could use them in writing was relatively higher (17.7\%). This is an expected outcome because speaking was usually the most neglected skill in language classrooms in Turkey (Ozsevik, 2010; Yıldırım, 2010). Besides, unlike writing, speaking is more spontaneous allowing no time for reviewing and revision. Likewise, most of the participants did not find their knowledge of English proverbs sufficient for their teaching of English effectively (item $35,75.4 \%, M=2.05)$.

In brief, although a majority of the participants knew for what purposes to use English proverbs and could identify them in listening and reading texts even if they were unable to comprehend them, it can be concluded that many of them did not have a good command of English proverbs. This is the case in Liontas's study (2002) which revealed that many of the second language learners were not satisfied with their knowledge of idiomatic expressions. Similarly, Turkol (2003) who more directly investigated proverb familiarity of Turkish non-native speakers of English found their lack of familiarity with proverbs. Considering the role of English classrooms as the main input provider in EFL contexts such as Turkey, insufficient knowledge of proverbs could be the result of poor proverb instruction at high school.

\subsection{What are EFL student-teachers' perceptions about their high-school English teachers' practices in teaching proverbs in the classroom?}

A majority of the participants thought that their English teachers at high school had not taught English proverbs sufficiently (item 36, 73.8\%, $M=2.10$ ) and hence, did not use to refer to their syntactic, semantic, pragmatic and literary aspects (See Table 3). That is only $8 \%$ of the participants considered their teachers' practice of teaching proverbs as sufficient. However, with respect to the items 37-42 about the aspects of proverbs studied, a relatively higher number of the participants were of the opinion that their teachers used to refer to the importance of English proverbs for communication (item 37, 28.3\%, $M=2.56$ ) and focus on their meanings (item 39, $26.4 \%, M=2.53)$. 
Table 3. Teaching of English proverbs by English teachers at high school

\begin{tabular}{|c|c|c|c|c|c|c|c|c|c|c|c|}
\hline \multirow[b]{2}{*}{ ITEM } & \multicolumn{2}{|c|}{$\begin{array}{l}1 \text { Strongly } \\
\text { Disagree }\end{array}$} & \multicolumn{2}{|c|}{2 Disagree } & \multicolumn{2}{|c|}{3 Neutral } & \multicolumn{2}{|c|}{4 Agree } & \multicolumn{2}{|c|}{5 Strongly Agree } & \multirow[t]{2}{*}{ Mean } \\
\hline & $\mathrm{N}$ & $\%$ & $\mathrm{~N}$ & $\%$ & $\mathrm{~N}$ & $\%$ & $\mathrm{~N}$ & $\%$ & $\mathrm{~N}$ & $\%$ & \\
\hline 36 & 49 & 26.2 & 89 & 47.6 & 34 & 18.2 & 12 & 6.4 & 3 & 1.6 & 2.10 \\
\hline 37 & 39 & 20.9 & 65 & 34.8 & 30 & 16.0 & 46 & 24.6 & 7 & 3.7 & 2.56 \\
\hline 38 & 55 & 29.6 & 85 & 45.7 & 30 & 16.1 & 15 & 8.1 & 1 & .5 & 2.04 \\
\hline 39 & 37 & 19.9 & 67 & 36.0 & 33 & 17.7 & 44 & 23.7 & 5 & 2.7 & 2.53 \\
\hline 40 & 41 & 21.9 & 60 & 32.1 & 42 & 22.5 & 40 & 21.4 & 4 & 2.1 & 2.50 \\
\hline 41 & 43 & 23.0 & 60 & 32.1 & 40 & 21.4 & 40 & 21.4 & 4 & 2.1 & 2.48 \\
\hline 42 & 61 & 32.6 & 89 & 47.6 & 25 & 13.4 & 12 & 6.4 & 0 & .0 & 1.94 \\
\hline 43 & 47 & 25.1 & 78 & 41.7 & 38 & 20.3 & 22 & 11.8 & 2 & 1.1 & 2.22 \\
\hline 44 & 35 & 18.9 & 48 & 25.9 & 48 & 25.9 & 45 & 24.3 & 9 & 4.9 & 2.70 \\
\hline 45 & 51 & 27.3 & 86 & 46.0 & 24 & 12.8 & 23 & 12.3 & 3 & 1.6 & 2.15 \\
\hline 46 & 50 & 26.7 & 71 & 38.0 & 32 & 17.1 & 32 & 17.1 & 2 & 1.1 & 2.28 \\
\hline 47 & 58 & 31.0 & 92 & 49.2 & 23 & 12.3 & 12 & 6.4 & 2 & 1.1 & 1.97 \\
\hline 48 & 49 & 26.2 & 84 & 44.9 & 26 & 13.9 & 25 & 13.4 & 3 & 1.6 & 2.19 \\
\hline 49 & 44 & 23.5 & 83 & 44.4 & 36 & 19.3 & 21 & 11.2 & 3 & 1.6 & 2.23 \\
\hline 50 & 39 & 20.9 & 67 & 35.8 & 39 & 20.9 & 39 & 20.9 & 3 & 1.6 & 2.47 \\
\hline 51 & 38 & 20.4 & 48 & 25.8 & 41 & 22.0 & 51 & 27.4 & 8 & 4.3 & 2.69 \\
\hline 52 & 76 & 40.6 & 75 & 40.1 & 21 & 11.2 & 14 & 7.5 & 1 & .5 & 1.87 \\
\hline 53 & 58 & 31.0 & 64 & 34.2 & 35 & 18.7 & 23 & 12.3 & 7 & 3.7 & 2.24 \\
\hline 54 & 39 & 20.9 & 58 & 31.0 & 24 & 12.8 & 52 & 27.8 & 14 & 7.5 & 2.70 \\
\hline 55 & 53 & 28.3 & 67 & 35.8 & 38 & 20.3 & 27 & 14.4 & 2 & 1.1 & 2.24 \\
\hline
\end{tabular}

As for their high school English teachers' use of proverbs in teaching various language skills and components, more than half of the respondents indicated that their teachers had not used English proverbs much in the teaching of all the language skills and components, in particular in the teaching of listening skill (item $47,80.2 \%$, $M=1.97$ ), pronunciation (item $45,73.3 \%, M=2.15$ ), speaking skill (item $48,71.1 \%, M$ $=2.19$ ), grammar (item $43,66.8 \%, M=2.22$ ) and writing skill (item $49,67.9 \%, M=$ 2.23). On the other hand, it is found that some of respondents' teachers had taught English proverbs by comparing them with Turkish proverbs (item 51, 31.7\%, $M=$ 2.69 ), in teaching vocabulary (item $44,29.2 \%, M=2.70$ ), culture (item $50,22.5 \%, M=$ 2.47) and reading skill (item $46,18.2 \%, M=2.28$ ) (See Table 3) with vocabulary component having the highest mean in terms of proverb teaching. The interview results also verify that a relatively more proverbs had been encountered in the teaching of vocabulary and reading skill. This is convincing because the teaching of other skills had usually been neglected in their English classrooms as one of the students pointed out:

I developed only the skills of answering multiple-choice questions and reading at high school. I don't think enough resources on speaking and listening skills were provided for us. (S4) 
Table 4. Kinds of materials used by English teachers at high school

\begin{tabular}{lllll}
\hline \multicolumn{1}{l}{ Materials } & \multicolumn{3}{l}{ Yes } & No \\
\cline { 2 - 5 } Dictionary & $\mathrm{N}$ & $\%$ & $\mathrm{~N}$ & $\%$ \\
\cline { 2 - 5 } Proverb lists & 13 & 7.1 & 170 & 92.9 \\
Proverb worksheet & 9 & 4.9 & 174 & 95.1 \\
Texts & 16 & 8.7 & 167 & 91.3 \\
Materials from real life & 15 & 8.2 & 168 & 91.8 \\
Games & 19 & 10.4 & 164 & 89.6 \\
Flashcards & 2 & 1.1 & 181 & 98.9 \\
\hline
\end{tabular}

With respect to the teachers' efforts in dealing with English proverbs, the bulk of the respondents thought that no special time had been allocated by their English teachers for the teaching of English proverbs (item 52, 80.7\%, $M=1.87$ ). For instance, many of them did not agree that their teachers had adapted the coursebooks and made the necessary modifications to make them more suitable and effective for the teaching of proverbs (item 53, 65.2\%, $M=2.24$ ). Besides, only 36 of the studentteachers (19.7\%) reported that their English teachers had made use of materials other than the coursebooks to teach proverbs (Part D, question 1) but according to some of the interviewees $(N=4)$, the extra materials (e.g., proverb lists) had been mostly used for self-study without explicit instruction. Regarding the supplementary materials used, the students indicated that their teachers had mostly used materials from real life $(10.4 \%)$, worksheet $(8.7 \%)$, texts $(8.2 \%)$ and dictionaries $(7.1 \%)$ (Table 4$)$.

Interview findings support the questionnaire results with respect to the studentteachers' perceptions about their English teachers' practices in teaching proverbs in the classroom. 17 of the 21 interviewees stated that their teachers had almost not taught any English proverbs and attributed this to the exam and grammar oriented instruction in the classroom. In relation to this, one of the interviewees said:

Language education at high and middle schools is devoted to grammar. We were always reminded of the exams that we were supposed to take and our desire to learn speaking was ignored. We had 13 hours of English. One hour of this can easily be allocated for English proverbs, one hour for everyday language and speaking practice using English proverbs. (S5)

According to four of the participants, despite some of their teachers' attempt to allocate some time for proverb teaching, it was still insufficient due to the priority given to grammar teaching. Even when the teachers tried to draw the students' attention to some proverbs and other idiomatic expressions encountered in their lessons, the students whose focus was on the exams used to find it unnecessary, which was made clear by one of the interviewees as stated below:

One of our teachers was actually preparing us for university but we did not like him/her much; in other words, we wanted other teachers to come because others prepared us for the exam. We wished that we had done more tests but now I realize... now I say that I wish we had known the value of that teacher. (S6) 
As some of the interviewees $(\mathrm{N}=12)$ have reported, their high school teachers' most common practice was talking about the proverbs when encountered in texts either by comparing them with the Turkish proverbs or by simply telling their meaning.

The results obtained in this section confirm the findings in other studies (Coskun, 2011; Kızıldağ, 2009; Özsevik, 2010; Yıldırım, 2010) which have shown that the English language exam has a negative impact on classroom practices. In addition, the finding that the participants' teachers had paid scant attention to proverbs that appear in materials is similar to the finding of Hanzen's study (2007) where some of the teachers also pointed out that they used proverbs as time-fillers in class when there was some extra time left. Even though the education system did not seem to allow for instruction on proverbs in the case of the participants' high school teachers, the literature review on various features of proverbs has revealed that proverbs can contribute to the development of not only pragmatic competence but also organizational competence. That is to say, teaching proverbs does not mean disregarding the teaching of traditionally emphasized language components and skills such as grammar and reading. On the contrary, it can play a role in their teaching while at the same time helping to move beyond to other components in second language teaching by integrating culture, figurative language and functional language.

\subsection{What are EFL student-teachers' perceptions about the sufficiency of the English coursebooks they used at high school in dealing with proverbs?}

A majority of the respondents thought that their high school coursebooks had not dealt with English proverbs adequately (item 57, 81.3\%, $M=1.89$ ) (Table 5). In comparison with the responses to item 36 about the adequacy of English teachers' practices in dealing with English proverbs, it is seen that the number of the respondents agreeing on the sufficiency of their coursebooks in terms of proverb instruction is relatively lower. Likewise, responses to item 56 show that only $14.4 \%$ ( $M=2.19)$ of the participants thought that they had learned most of the English proverbs from the coursebooks they studied at high school whereas $35.3 \%$ thought that they had learned most of them not from the coursebooks but only from their English teachers at high school (item 54, $M=2.70$ ). As a result, it can be concluded that despite the respondents' view with regard to the inadequacy of both their English teachers and coursebooks in dealing with English proverbs, it was still their teachers from whom they reported to have benefited comparatively more in terms of proverb instruction.

In relation to the aspects of English proverbs covered in the English coursebooks, the majority believed that their coursebooks had not made reference to the various features of English proverbs (items 59-64) in particular the literary (item 62, 81.3\%, $M=1.84$ ) and syntactic (item $60,77 \%, M=1.92$ ) aspects of proverbs. This is consistent with the finding regarding the practices of the participants' English teachers in dealing with the aspects of the proverbs in the classroom as shown in 
Table 3 since they had also particularly disregarded the literary and syntactic aspects of proverbs as reported by most of the participants. On the other hand, when the percentages of agreement with respect to their English coursebooks (11\%, See Table 5) and their English teachers (19.45\%, See Table 3) are compared in terms of their focus on the various aspects of English proverbs, a relatively higher percentage is obtained in the latter case (i.e, English teachers). This can be explained by some of the teachers' tendency to present more than what the coursebooks had offered.

As for the ways the English coursebooks dealt with proverbs, most of the participants thought that their coursebooks had not presented proverbs in any of the ways specified in the items $65-68$. To illustrate, $76.5 \%$ of the respondents indicated that their coursebooks had included no activities designed specifically for the purpose of teaching English proverbs and for reinforcing proverb knowledge (item 68, $M=$ 2.01). On the other hand, a relatively higher number of them thought that their coursebooks had presented English proverbs in texts (item 66, 26.5\%, $M=2.57$ ) and introduced them by means of materials from real life (item 67, 19.8\%, $M=2.41$ ). However, it is not clear whether an explicit instruction had been provided on the proverbs encountered in texts or whether those proverbs were inserted into the texts particularly for the purpose of teaching them.

As presented in Table 5, according to the respondents' views, the coursebooks used by the majority incorporated proverbs in the teaching of not all the language skills and components (items 69-72). Similar to the student-teachers' views about their English teachers' practices, the coursebooks were reported to have employed relatively more proverbs in the teaching of vocabulary (item $70,23.5 \%, M=2.42$ ), culture (item $76,16.8 \%, M=2.25$ ) and reading skill (item $73,14 \%, M=2.18$ ). As the mostly emphasized language skill and component in the Turkish context, the English coursebooks involved relatively more use of proverbs in the teaching of reading skill and vocabulary, whether included for a an instructional purpose or not. In addition, despite the importance also given to grammar, the respondents reported that their coursebooks had not made use of proverbs in grammar teaching (item 69, 74.3\%, $M=$ 2.00 ), which might be because grammar and proverbs were usually seen at the two opposite ends of the continuum and heavy grammar instruction was viewed as the main obstacle to teaching proverbs by many participants. It appears that students, teachers and coursebook writers were not aware of the role proverbs can play in grammar teaching as well as in the teaching of other language skills and components.

Table 5. Teaching of English proverbs in English coursebooks used at high school

\begin{tabular}{|c|c|c|c|c|c|c|c|c|c|c|c|}
\hline & \multicolumn{2}{|c|}{$\begin{array}{l}1 \text { Strongly } \\
\text { Disagree }\end{array}$} & \multicolumn{2}{|c|}{2 Disagree } & \multicolumn{2}{|c|}{3 Neutral } & \multicolumn{2}{|c|}{4 Agree } & \multicolumn{2}{|c|}{5 Strongly Agree } & \multirow[t]{2}{*}{ Mean } \\
\hline ITEM & $\mathrm{N}$ & $\%$ & $\mathrm{~N}$ & $\%$ & $\mathrm{~N}$ & $\%$ & $\mathrm{~N}$ & $\%$ & $\mathrm{~N}$ & $\%$ & \\
\hline 56 & 55 & 29.4 & 72 & 38.5 & 33 & 17.6 & 23 & 12.3 & 4 & 2.1 & 2.19 \\
\hline 57 & 69 & 36.9 & 83 & 44.4 & 21 & 11.2 & 14 & 7.5 & 0 & .0 & 1.89 \\
\hline 58 & 66 & 35.3 & 70 & 37.4 & 30 & 16.0 & 16 & 8.6 & 5 & 2.7 & 2.06 \\
\hline 59 & 61 & 33.0 & 69 & 37.3 & 37 & 20.0 & 18 & 9.7 & 0 & .0 & 2.06 \\
\hline
\end{tabular}




\begin{tabular}{|c|c|c|c|c|c|c|c|c|c|c|c|}
\hline 60 & 68 & 36.4 & 76 & 40.6 & 33 & 17.6 & 10 & 5.3 & 0 & .0 & 1.92 \\
\hline 61 & 59 & 31.6 & 64 & 34.2 & 37 & 19.8 & 26 & 13.9 & 1 & .5 & 2.18 \\
\hline 62 & 74 & 39.6 & 78 & 41.7 & 26 & 13.9 & 9 & 4.8 & 0 & .0 & 1.84 \\
\hline 63 & 54 & 28.9 & 64 & 34.2 & 39 & 20.9 & 27 & 14.4 & 3 & 1.6 & 2.26 \\
\hline 64 & 55 & 29.4 & 63 & 33.7 & 39 & 20.9 & 29 & 15.5 & 1 & .5 & 2.24 \\
\hline 65 & 72 & 38.7 & 69 & 37.1 & 24 & 12.9 & 18 & 9.7 & 3 & 1.6 & 1.98 \\
\hline 66 & 41 & 22.2 & 48 & 25.9 & 47 & 25.4 & 47 & 25.4 & 2 & 1.1 & 2.57 \\
\hline 67 & 47 & 25.1 & 59 & 31.6 & 44 & 23.5 & 32 & 17.1 & 5 & 2.7 & 2.41 \\
\hline 68 & 65 & 34.8 & 78 & 41.7 & 24 & 12.8 & 18 & 9.6 & 2 & 1.1 & 2.01 \\
\hline 69 & 67 & 35.8 & 72 & 38.5 & 30 & 16.0 & 17 & 9.1 & 1 & .5 & 2.00 \\
\hline 70 & 47 & 25.1 & 63 & 33.7 & 33 & 17.6 & 40 & 21.4 & 4 & 2.1 & 2.42 \\
\hline 71 & 65 & 34.9 & 83 & 44.6 & 25 & 13.4 & 13 & 7.0 & 0 & .0 & 1.92 \\
\hline 72 & 68 & 36.6 & 84 & 45.2 & 25 & 13.4 & 9 & 4.8 & 0 & .0 & 1.87 \\
\hline 73 & 51 & 27.4 & 79 & 42.5 & 30 & 16.1 & 23 & 12.4 & 3 & 1.6 & 2.18 \\
\hline 74 & 57 & 30.6 & 81 & 43.5 & 26 & 14.0 & 20 & 10.8 & 2 & 1.1 & 2.08 \\
\hline 75 & 61 & 32.8 & 72 & 38.7 & 29 & 15.6 & 24 & 12.9 & 0 & .0 & 2.09 \\
\hline 76 & 54 & 29.2 & 66 & 35.7 & 34 & 18.4 & 27 & 14.6 & 4 & 2.2 & 2.25 \\
\hline 77 & 59 & 31.7 & 64 & 34.4 & 38 & 20.4 & 22 & 11.8 & 3 & 1.6 & 2.17 \\
\hline
\end{tabular}

Interview findings further explain the questionnaire results in relation to the student-teachers' perceptions about the sufficiency of their English coursebooks in dealing with proverbs. Unexpectedly, 5 of the 21 interviewees had not followed any main coursebook at all but instead used test and grammar books and thus, they could not comment much on the quality of the coursebooks in terms of proverb instruction. Considering those who used coursebooks at high school as the main source in their classes, most of them (40\%) studied only the parts required for the exam and hence, left out listening, speaking and writing sections. With regard to the proverb instruction in the coursebooks used by the interviewees, 16 of them indicated that they had rarely encountered proverbs in their coursebooks while some of them explained that their coursebooks had usually included proverbs as additional components and at random. According to most of these participants, proverbs appeared at the end of the units in their coursebooks which were sometimes accompanied by mechanic exercises such as fill-in-the-blanks or which were presented simply in lists and sometimes used not for a teaching purpose but for fun. Proverbs were also reported to have been incorporated in texts and vocabulary sections in some of the coursebooks used by the participants. In relation to this, one of the interviewees stated:

Not much place was given (to proverbs in the coursebooks). Sometimes I used to see them in texts but we didn't feel the need to pay attention to them which means that there weren't many of them. In other words, if there had been many, we would have felt the need to learn them in order to understand. (S7)

Regarding the issue about the place of proverbs in the English coursebooks, Vanyushkina-Holt (2005) describes proverbs given in lists as "homeless orphans" because "they do not belong anywhere and their future is hopeless" (p.123). Even when proverbs appear in texts and titles, in many cases they just seem to be there 
without any explicit focus on them by means of some activities. They are only used to strengthen the ideas in the passage. This is also found to be the case with the proverbs in Russian textbooks examined by Vanyushkina-Holt (2005), who argues that students will either not recognize them or skip them as unimportant details, which then makes the use of proverbs suitable only for native speakers who can automatically identify and comprehend them. Furthermore, when proverbs are encountered in such cases, it depends on the student's interest and teacher's attitudes to explicitly focus on them

When the interviewees were asked about whether the coursebooks should integrate proverbs, they all expressed a wish for a place of proverbs in the coursebooks as shown in the following comment:

Yes, they (coursebooks) should give place (to proverbs). Someone who is going to graduate from foreign language departments and who is going to work as an English teacher or as a translator certainly needs to learn proverbs. As a result, English will be a part of his/her life and proverbs are a part of English...(S8)

The findings in general confirm the result of Driscoll, Earl and Cable's study (2013) which revealed that although cultural dimension in language teaching is considered important, it is not integrated systematically.

\section{Conclusion}

Considering the importance of proverbs for the development of student-teachers' communicative competence and hence, for their professional development, this study reveals the extent to which proverbs had been taught to EFL student-teachers to help them build on their communicative competence. The findings show that the majority of the EFL student-teachers had positive attitudes towards learning and teaching English proverbs but at the same time they thought that they did not have a good command of English proverbs and that their English teachers and coursebooks at high school had not taught proverbs sufficiently. Besides, it is found that the participants' conceptualizations of proverbs reflect traditional definitions, which suggests that the definitions of proverbs as presented in instructional materials and the examples provided should be updated to keep up with the recent developments in proverb use as a result of the changes in the nature of communication. The results of this study have, thus, highlighted the need for proverb teaching in EFL classrooms with reference to the natural language use in various forms of communication. To meet this need, when designing materials and planning lessons, it should be kept in mind that knowledge of English phraseology and proverbs in particular constitutes an important component of learners' language competence because as part of cultural references, figurative, functional and formulaic language, proverbs can help to enhance both organizational and pragmatic competence as included in Bachman's model. In an EFL setting such as Turkey where there is limited exposure to English outside the classroom, English language teachers and coursebooks carry an utmost importance in teaching English proverbs. This implies a need to train prospective teachers and design instructional materials and curriculum in a way that encourages 
the integration of various aspects of English proverbs to contribute to the development of learners' communicative competence. Even if the heavily-loaded programs and grammar-oriented exams are seen to be an obstacle to the teaching of cultural and pragmatic aspects of English in high schools, proverbs can then be suggested as practical language tools to introduce language structures, vocabulary, culture, non-literal language and pragmatics at the same time. Therefore, despite the importance of exam results and competition among the students who are to take the university entrance exam, "teachers should remember the features 'creativity and flexibility' usually listed among the features associated with 'good teachers' and should try to find ways to presenting students with the cultural information" (Hatipoğlu, 2009, p. 356).

All this suggests that there should be collaboration among researchers, coursebooks writers, curriculum designers, administrators, teachers and students. This study can serve as a guideline for these stakeholders in writing the curriculum, designing the instructional materials and planning lessons. Moreover, when educating studentteachers, proverbs can be incorporated in the language classrooms to contribute to the development of their language competence and awareness. In this way, these studentteachers can first of all enhance their own communicative competence and then know what aspects of language and culture to transfer to language learners and use their proverb knowledge in designing instructional materials and adapting textbooks that are insufficient in terms of proverb instruction.

\section{Acknowledgement}

This study comes from a master's thesis that was submitted by the first author to Middle East Technical University (Can, 2011).

\section{References}

Alexander, R. J. (1984). Fixed expressions in English: reference books and the teacher. ELT Journal, 38(2), 127-134.

Al-Issa, A. (2005). The role of English language culture in the Omani language education system: An ideological perspective. Language, Culture and Curriculum, 18(3), 258-270.

Alkaya, E. (2001). Tatar Türkçesindeki dil ve söz ile ilgili atasözleri üzerine bir değerlendirme. Firat Üniversitesi Sosyal Bilimler Dergisi, 11(2), 55-76.

Arıkan, A., \& Tekir, S. (2007). An analysis of English language teaching coursebooks by Turkish writers: "Let's speak English 7" example. International Journal of Human Sciences, 4(2), 1-18.

Bachman, L. F. (1990). Fundamental considerations in language testing. Oxford: Oxford University Press.

Bessmertnyi, A. (1994). Teaching cultural literacy to foreign-language students. English Teaching Forum, 32(4), 24-27.

Bulut, T., \& Çelik-Yazıcı, İ. (2004). Idiom processing in L2: Through rose-colored glasses. The Reading Matrix, 4(2), 105-116. 
Can, N. (2011). A proverb learned is a proverb earned: Future English teachers' experiences of learning English proverbs in Anatolian Teacher Training High Schools in Turkey (Unpublished master's thesis). Middle East Technical University, Ankara.

Charteris-Black, J. (1995). Proverbs in communication. Journal of Multilingual Multicultural Development, 16, 259-268.

Ciccarelli, A. (1996). Teaching culture through language: Suggestions for the Italian language class. Italica, 73(4), 563-576.

Cohen, L., Manion, L., \& Morrison, K. (2007). Research methods in education. New York, NY: Routledge.

Cooper, T. C. (1999). Processing of idioms by L2 learners of English. TESOL Quarterly, 33(2), 233-262.

Coşkun, A. (2011). Investigation of the application of communicative language teaching in the English language classroom: A case study on teachers' attitudes in Turkey. Journal of Linguistics and Language Teaching, 2(1), 1-27.

Cruz, S. (1995). Actions speak louder than words: Understanding figurative proverbs (Unpublished doctoral dissertation). University of California, California. Retrieved from ProQuest Dissertations \& Theses. (AAT 9538666)

Çakir, A. (2016). Raising awareness on the Turkish learners of English about the arbitrary nature of figurative expressions. European Journal of Multidisciplinary Studies, 1(2), 248252.

Çakır, İ. (2010). The frequency of culture-specific elements in the ELT coursebooks at elementary schools in Turkey. Novitas-ROYAL (Research on Youth and Language), 4(2), 182-189.

D'Angelo, F. J. (1977). Some uses of proverbs. College Composition and Communication, 28(4), 365-369.

Dobrovol'skij, D., \& Piirainen, E. (2005). Figurative language: Cross-cultural and crosslinguistic perspectives. Oxford: Elsevier.

Dörnyei, Z. (2003). Questionnaire in second language research: Construction, administration, and processing. Mahwah, NJ: Lawrence Erlbaum Associates.

Drew, P., \& Holt, E. (1998). Figures of speech: Figurative expressions and the management of topic transition in conversation. Language and Society, 27, 495-522.

Driscoll, P., Earl, J., \& Cable, C. (2013). The role and the nature of the cultural dimension in primary modern languages. Language, Culture and Curriculum, 26(2), 146-160.

Dundes, A. (1975). On the structure of the proverb. Proverbium, 25, 961-973.

Eker, S. (2006). Çağdaş Türk dili. Ankara: Grafiker Yayınları.

Elkılıç, G. (2008). Turkish students' understanding of transparent and opaque idioms in English in reading as well as in speaking. Journal of Language and Linguistic studies, 4(2), 27-41.

Ellis, N. C. (2008). Phraseology: The periphery and the heart of language. In F. Meunier \& S. Granger (Eds.), Phraseology in foreign language learning and teaching (pp. 1-15). Amsterdam: John Benjamins.

Foddy, W. (1993). Constructing questions for interviews and questionnaires: Theory and practice in social research. Cambridge: Cambridge University Press.

Göçmen, E., Göçmen, N., \& Ünsal, A. (2012). The role of idiomatic expressions in teaching languages and cultures as part of a multilingual approach. Procedia-Social and Behavioral Sciences, 55, 239-247.

Gözpınar, H. (2014). Activities to promote the use of proverbs to develop foreign language skills. Modern Journal of Language Teaching Methods (MJLTM), 4(4), 107-112. 
Granger, S., \& Paquot, M. (2008). Disentangling the phraseological web. In S. Granger \& F. Meunier (Eds.), Phraseology: An interdisciplinary perspective (pp. 27-51). Amsterdam: John Benjamins.

Hanzen, M. (2007). "When in Rome, do as the Romans do": Proverbs as a part of EFL teaching. Högskolan För Larande Och Kommunikation (HLK), 36, 1-24.

Harnish, R. M. (1993). Communicating with proverbs. Communication and Cognition, 26(3/4), 265-290.

Hatipoğlu, Ç. (2009). Do we speak the same culture?: Evidence from university students in the Foreign Language Education Departments. Proceedings of the International Congress of Comparative Literature and the Teaching of Literature and Language: We Speak the Same Culture, 29 April-1 May 2009, Gazi University, Ankara, Turkey, pp. 343-357.

Hernadi, P., \& Steen, F. (1999). The tropical landscapes of proverbia: A crossdisciplinary travelogue. Style, 33(1), 1-20.

Hirsch, E. D., Kett, J. F., \& Trefil, J. (2002). The new dictionary of cultural literacy. New York, NY: Houghton Mifflin.

Holden, M. H., \& Warshaw, M. (1985). A bird in the hand and a bird in the bush: Using proverbs to teach skills and comprehension. The English Journal, 74(2), 63-67.

Irujo, S. (1986). Don't put your leg in your mouth: Transfer in the acquisition of idioms in a second language. TESOL Quarterly, 20(2), 287-304.

Kaya, F. B., \& Yilmaz, M. Y. (2018). The frequency of using idioms in writing for the students learning Turkish as a foreign language. Educational Research and Reviews, 13(16), 602 608.

Kemper, S. (1981). Comprehension and the interpretation of proverbs. Journal of Psycholinguistic Research, 10(2), 179-189.

Khan, Ö., \& Can Daşkın, N. (2014). "You reap what you sow"- Idioms in materials designed by EFL teacher-trainees. Novitas-ROYAL (Research on Youth and Language, 8(2), 97-118.

Kızıldağ, A. (2009). Teaching English in Turkey: Dialogues with teachers about the challenges in public primary schools. International Electronic Journal of Elementary Education, 1(3), 188-201.

Kowbel, S. L. (2005). Every thesis has a silver lining: How proverbs are processed and understood (Unpublished doctoral dissertation). University of Calgary, Alberta. Retrieved from ProQuest Dissertations \& Theses.

Lakoff, G., \& Turner, M. (1989). More than cool reason: A field guide to poetic metaphor. Chicago: The University of Chicago Press.

Lazar, I. (2003). Introducing Mirrors and windows: An intercultural communication textbook. In I. Lazar (Ed.), Incorporating intercultural communicative competence in language teacher education (pp. 69-72). Kapfenberg: Council of Europe Publishing.

Liontas, J. I. (2002). Exploring second language learners' notion of idiomaticity. System, 30, 289-313.

Litovkina, A. T. (2000). A proverb a day keeps boredom away. Pécs-Szekszárd: IPFKönyvek.

Litovkina, A. T., \& Mieder, W. (2006). Old proverbs never die, they just diversify. Veszprem, Hungary: University of Veszprem Press.

Littlemore, J., \& Low, G. (2006a). Figurative thinking and foreign language learning. New York, NY: Palgrave Macmillan.

Littlemore, J., \& Low, G. (2006b). Metaphoric competence, second language learning, and communicative language ability. Applied Linguistics, 27(2), 268-294.

Lund, R. J. (1991). A comparison of second language listening and reading comprehension. The Modern Language Journal, 75(2), 196-204. 
Mackey, A., \& Gass, S. M. (2005). Second language research: Methodology and design. Mahwah, NJ: Lawrence Erlbaum.

McWilliam, N. (1997). Lexical meaning in the multilingual classroom: The word-weaving project. Language, Culture and Curriculum, 10(1), 14-29.

Mieder, W. (2004). Proverbs - A Handbook. Westport, CT; Greenwood Press.

Mieder, W. (2007). Proverbs as cultural units or items of folklore. In H. Burger, D. Dobrovol'skij, P. Kühn \& N. R. Norrick (Eds.), Phraseology: An international handbook of contemporary research (pp. 394- 414). Berlin, Germany: Walter de Gruyter.

Mieder, W., \& Holmes, D. (2000). Children and proverbs speak the truth. Burlington, Vermont: Queen City Printers.

Milner, G. (1971). The quartered shield: Outline of a semantic taxonomy. In E. Ardener (Ed.), Social anthropology and language, (pp. 243-269). London: Tavistock.

Nippold, M. A., Allen, M. M., \& Kirsch, D. I. (2001). Proverb comprehension as a function of reading proficiency in preadolescents. Language, Speech, and Hearing Services in Schools, 32(2), 90-100.

Norrick, N. R. (1985). How proverbs mean: Semantic studies in English proverbs. Berlin: Mouton.

Norrick, N. R. (2007). Proverbs as set phrases. In H. Burger, D. Dobrovol'skij, P. Kühn \& N. R. Norrick (Eds.), Phraseology: An international handbook of contemporary research (pp. 381394). Berlin, Germany: Walter de Gruyter.

Nuessel, F. (2003). Proverbs and metaphoric language in second-language acquisition. In W. Mieder (Ed.), Cognition, comprehension and communication. A decade of North American proverb studies (pp. 395-412). Hohengehren: Schneider-Verlag.

Obeng, S. G. (1996). The proverb as a mitigating and politeness strategy in Akan discourse. Anthropological Linguistics, 38(3), 521-546.

O'Keeffe, A., McCarthy, M., \& Carter, R. (2007). From corpus to classroom: Language use and language teaching. Cambridge: Cambridge University Press.

Ozsevik, Z. (2010). The use of communicative language teaching (CLT): Turkish EFL teachers' perceived difficulties in implementing CLT in Turkey (Unpublished master's thesis). University of Illinois, Illinois. Retrieved February, 23, 2011, from https://www.ideals.illinois.edu/handle/2142/16211

Prodromou, L. (2003). Idiomaticity and the non-native speaker. English Today 74, 19(2), 42-48.

Richmond, E. B. (1987). Utilizing proverbs as a focal point to cultural awareness and communicative competence: Illustrations from Africa. Foreign Language Annals, 20(3), 213216.

Ridout, R., \& Witting, C. (1969). English proverbs explained. Cavaye Place, London: Pan Books.

Schuman, H., \& Presser, S. (1996). Questions and answers in attitude surveys: Experiments on question form, wording, and context. Thousand Oaks, CA: SAGE.

Searle, J. R. (1975). Indirect speech acts. Syntax and Semantics, 3, 59-82.

Sinclair, J. (1992). Shared knowledge, In Proceedings of the Georgetown University Roundtable in Linguistics and Pedagogy: The State of the Art (pp. 496-499).Georgetown, NW: Georgetown University Press.

Taylor, A. (1931). The Proverb. Cambridge, MA: Harvard University Press.

Temple, J. G., \& Honeck, R. P. (1999). Proverb comprehension: The primacy of literal meaning. Journal of Psycholinguistic Research, 28(1), 41-70. 
Thomas, A. (1987). Language teacher competence and language teacher education. In $\mathrm{R}$. Bowers (Ed.), Language teacher education: An integrated programme for ELT teacher training (pp. 33-42). London: British Council, Modern English Publications.

Turkol, S. (2003). Proverb familiarity and interpretation in advanced non-native speakers of English (Unpublished master's thesis). Southern Connecticut State University, Connecticut. Retrieved from ProQuest Dissertations \& Theses. (AAT 1414311)

Turner, N. E. (1995). The role of literal meaning in proverb comprehension (Unpublished doctoral dissertation). The University of Western Ontario, London. Retrieved from ProQuest Dissertations \& Theses. (AAT 0623)

Ulusoy Aranyosi, E. (2010). "Atasözü" neydi, ne oldu? [What was, and what now is, a "proverb"]. Milli folklor, 22(88), 5-15.

Vandergrift, L. (1999). Facilitating second language listening comprehension: acquiring successful strategies. ELT Journal, 53(3), 168-176.

Vanyushkina-Holt, N. (2005). Proverbial language and its role in acquiring a second language and culture (Unpublished doctoral dissertation). Retrieved from ProQuest Dissertations \& Theses. (AAT 3319175)

Vulchanova, M., Vulchanov, V. \& Stankova, M. (2011). "Idiom comprehension in the first language: a developmental study". VIAL-Vigo International Journal of Applied Linguistics, 8, 207-234.

Wray, A. (2000). Formulaic sequences in second language teaching: Principle and practice. Applied Linguistics, 21(4), 463-489.

Yano, Y. (1998). Underlying metaphoric conceptualization of learning and intercultural communication. Intercultural Communication Studies, 2(2), 129-137.

Yıldırım, Ö. (2010). Washback effects of a high-stakes university entrance exam: Effects of the English section of the university entrance exam on future English language teachers in Turkey. The Asian EFL Journal Quarterly, 12(2), 92-116.

Yorio, C. A. (1980). Conventionalized language forms and the development of communicative competence. TESOL Quarterly, 14(4), 433-442.

Yurtbaşı, M. (n.d.). How to learn English through proverbs. İstanbul: Arion. 


\section{Appendix A. The questionnaire designed for this study}

\section{PART A: YOUR UNDERSTANDING OF PROVERBS}

Briefly, write your definition of a proverb. If you think you can't write a definition, write down the words that come to your mind when you hear the word "proverb".

\section{PART B: YOUR ATTITUDE TOWARDS LEARNING AND TEACHING OF ENGLISH PROVERBS}

Some of the English proverbs: No pain, no gain; Better late than never; An apple a day keeps the doctor away; Beauty is only skin deep; Don't judge a book by its cover; $A$ friend in need is a friend indeed.

Please read the statements below and tick $(\checkmark)$ the most appropriate option. Make sure that your responses reflect your true and sincere thoughts.

\begin{tabular}{|c|c|c|c|c|c|}
\hline LEARNING AND TEACHING OF ENGLISH PROVERBS & 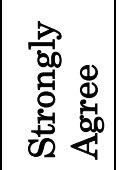 & 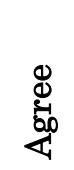 & 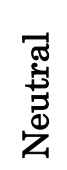 & 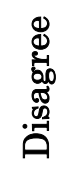 & 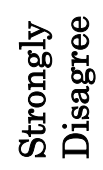 \\
\hline $\begin{array}{l}\text { 1. I believe learning English proverbs is an important part of } \\
\text { English language learning experience. }\end{array}$ & 5 & 4 & 3 & 2 & 1 \\
\hline $\begin{array}{l}\text { 2. Learning to use English proverbs is necessary for achieving } \\
\text { effective communication. }\end{array}$ & 5 & 4 & 3 & 2 & 1 \\
\hline $\begin{array}{l}\text { 3. Learning to use English proverbs in oral communication is } \\
\text { necessary for developing my speaking skills. }\end{array}$ & 5 & 4 & 3 & 2 & 1 \\
\hline $\begin{array}{l}\text { 4. Using proverbs when I give oral presentations in English } \\
\text { will make my speech more effective. }\end{array}$ & 5 & 4 & 3 & 2 & 1 \\
\hline $\begin{array}{l}\text { 5. Learning to use English proverbs in written communication } \\
\text { is necessary for developing my writing skills. }\end{array}$ & 5 & 4 & 3 & 2 & 1 \\
\hline $\begin{array}{l}\text { 6. Knowing English proverbs is important for me to } \\
\text { comprehend the reading texts better. }\end{array}$ & 5 & 4 & 3 & 2 & 1 \\
\hline $\begin{array}{l}\text { 7. Knowing English proverbs is important for me to } \\
\text { comprehend the listening texts better. }\end{array}$ & 5 & 4 & 3 & 2 & 1 \\
\hline $\begin{array}{l}\text { 8. Knowing English proverbs is important for me to } \\
\text { understand the target culture better. }\end{array}$ & 5 & 4 & 3 & 2 & 1 \\
\hline $\begin{array}{l}\text { 9. Knowing English proverbs is important for me to perceive } \\
\text { the cultural differences and similarities better. }\end{array}$ & 5 & 4 & 3 & 2 & 1 \\
\hline $\begin{array}{l}\text { 10. Knowing English proverbs is necessary for me to make } \\
\text { sense of the humours generated in English. }\end{array}$ & 5 & 4 & 3 & 2 & 1 \\
\hline 11. Learning English proverbs is important for me to get & 5 & 4 & 3 & 2 & 1 \\
\hline
\end{tabular}




\begin{tabular}{|l|l|l|l|l|l|}
\hline familiar with the English figurative expressions. & & & & \\
\hline $\begin{array}{l}\text { 12. Learning English proverbs is important for me to develop } \\
\text { my skill of expressing myself by using figurative language } \\
\text { in English. }\end{array}$ & 5 & 4 & 3 & 2 & 1 \\
\hline $\begin{array}{l}\text { 13. Knowing English proverbs is necessary for me to } \\
\text { understand the everyday language better. }\end{array}$ & 5 & 4 & 3 & 2 & 1 \\
\hline $\begin{array}{l}\text { 14. We might need to use English proverbs when we have to } \\
\text { communicate in English outside the classroom. }\end{array}$ & 5 & 4 & 3 & 2 & 1 \\
\hline $\begin{array}{l}\text { 15. We might need to recognize and understand English } \\
\text { proverbs when we have to communicate in English outside } \\
\text { the classroom. }\end{array}$ & 5 & 4 & 3 & 2 & 1 \\
\hline $\begin{array}{l}\text { 16. I think it is important to teach English proverbs in English } \\
\text { classrooms. }\end{array}$ & 5 & 4 & 3 & 2 & 1 \\
\hline $\begin{array}{l}\text { 17. I will definitely teach English proverbs when I become an } \\
\text { English teacher. }\end{array}$ & 5 & 4 & 3 & 2 & 1 \\
\hline $\begin{array}{l}\text { 18. I believe it is necessary to incorporate English proverbs in } \\
\text { English coursebooks. }\end{array}$ & 5 & 4 & 3 & 2 & 1 \\
\hline $\begin{array}{l}\text { 19. I think English proverbs should be a part of the English } \\
\text { language curriculum at high schools. }\end{array}$ & 5 & 4 & 3 & 2 & 1 \\
\hline $\begin{array}{l}\text { 20. I think it is important to encourage English language } \\
\text { learners to learn proverbs for effective communication. }\end{array}$ & 5 & 4 & 3 & 2 & 1 \\
\hline $\begin{array}{l}\text { If you have different opinions regarding the teaching and learning of English proverbs, please } \\
\text { specify them: }\end{array}$ & & \\
\hline
\end{tabular}

PART C: YOUR KNOWLEDGE OF PROVERBS

Please read the statements below and tick $(\checkmark)$ the most appropriate option. Make sure that your responses reflect your true and sincere thoughts.

\begin{tabular}{|c|c|c|c|c|c|}
\hline YOUR KNOWLEDGE OF PROVERBS & 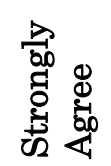 & 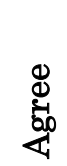 & 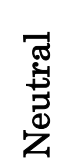 & 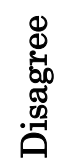 & 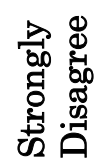 \\
\hline $\begin{array}{l}\text { 21. I have knowledge of the typical structures of English } \\
\text { proverbs. }\end{array}$ & 5 & 4 & 3 & 2 & 1 \\
\hline $\begin{array}{l}\text { 22. I have knowledge of the semantic features of English } \\
\text { proverbs (e.g., their themes, synonymous and antonymous } \\
\text { proverbs etc.). }\end{array}$ & 5 & 4 & 3 & 2 & 1 \\
\hline $\begin{array}{l}\text { 23. I have knowledge of the literary aspects of English } \\
\text { proverbs (e.g., use of metaphors, rhyme etc.) }\end{array}$ & 5 & 4 & 3 & 2 & 1 \\
\hline $\begin{array}{l}\text { 24. I have knowledge of the cultural aspects of English } \\
\text { proverbs. }\end{array}$ & 5 & 4 & 3 & 2 & 1 \\
\hline 25. I know in what situations to use English proverbs. & 5 & 4 & 3 & 2 & 1 \\
\hline 26. I know for what purposes to use English proverbs. & 5 & 4 & 3 & 2 & 1 \\
\hline $\begin{array}{l}\text { 27. I can recognize and understand English proverbs in } \\
\text { listening texts. }\end{array}$ & 5 & 4 & 3 & 2 & 1 \\
\hline 28. I can recognize English proverbs in listening texts even if I & 5 & 4 & 3 & 2 & 1 \\
\hline
\end{tabular}




\begin{tabular}{|l|l|l|l|l|l|}
\hline do not understand them. & & & & \\
\hline $\begin{array}{l}\text { 29. I can recognize and understand English proverbs in } \\
\text { reading texts. }\end{array}$ & 5 & 4 & 3 & 2 & 1 \\
\hline $\begin{array}{l}\text { 30. I can recognize English proverbs in reading texts even if I } \\
\text { do not understand them. }\end{array}$ & 5 & 4 & 3 & 2 & 1 \\
\hline $\begin{array}{l}\text { 31. I have difficulty comprehending the proverbs I come across } \\
\text { in English songs. }\end{array}$ & 5 & 4 & 3 & 2 & 1 \\
\hline $\begin{array}{l}\text { 32. I have difficulty comprehending the proverbs I come across } \\
\text { in English movies. }\end{array}$ & 5 & 4 & 3 & 2 & 1 \\
\hline 33. I can use English proverbs in writing in English. & 5 & 4 & 3 & 2 & 1 \\
\hline 34. I can use English proverbs in speaking in English. & 5 & 4 & 3 & 2 & 1 \\
\hline $\begin{array}{l}\text { 35. I think I know proverbs enough to contribute to my } \\
\text { teaching of English effectively. }\end{array}$ & 5 & 4 & 3 & 2 & 1 \\
\hline
\end{tabular}

\section{PART D: YOUR EXPERIENCE OF LEARNING ENGLISH PROVERBS}

1. Did your English teachers at High School employ materials other than coursebooks to teach English proverbs? $\square$ Yes $\square$ No

2. If your response to question 1 is YES, indicate what kinds of materials your English teachers used when teaching English proverbs. Tick $(\checkmark)$ the appropriate options given below.

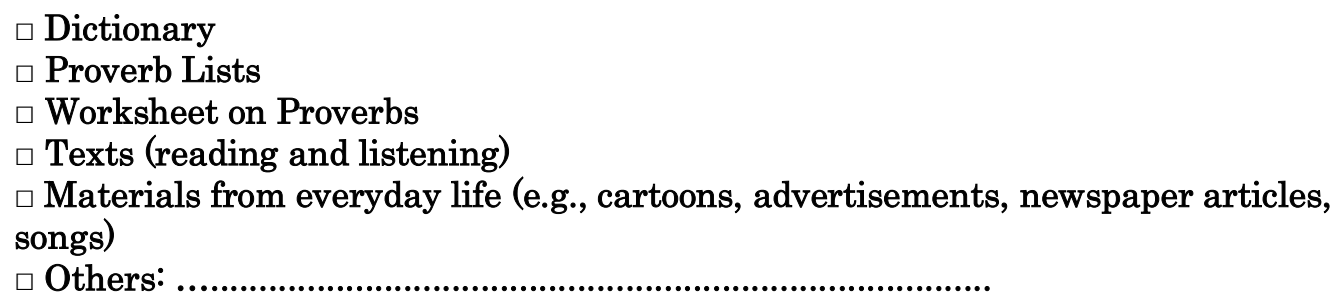

3. Please read the statements below and tick $(\checkmark)$ the most appropriate option. Make sure that your responses reflect your true and sincere thoughts.

\begin{tabular}{|c|c|c|c|c|c|}
\hline $\begin{array}{l}\text { TEACHING OF ENGLISH PROVERBS BY YOUR ENGLISH } \\
\text { TEACHERS AT HIGH SCHOOL }\end{array}$ & 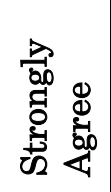 & 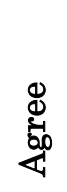 & 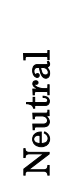 & 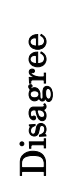 & 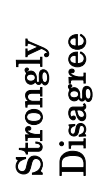 \\
\hline $\begin{array}{l}\text { 36. My English teachers at high school taught English proverbs } \\
\text { sufficient enough. }\end{array}$ & 5 & 4 & 3 & 2 & 1 \\
\hline $\begin{array}{l}\text { 37. My English teachers at high school used to mention the } \\
\text { importance of English proverbs in communication. }\end{array}$ & 5 & 4 & 3 & 2 & 1 \\
\hline $\begin{array}{l}\text { 38. My English teachers at high school used to dwell on the } \\
\text { structures of English proverbs. }\end{array}$ & 5 & 4 & 3 & 2 & 1 \\
\hline $\begin{array}{l}\text { 39. My English teachers at high school used to dwell on the } \\
\text { meanings of English proverbs. }\end{array}$ & 5 & 4 & 3 & 2 & 1 \\
\hline $\begin{array}{l}\text { 40. My English teachers at high school used to teach in what } \\
\text { situations to use English proverbs. }\end{array}$ & 5 & 4 & 3 & 2 & 1 \\
\hline
\end{tabular}




\begin{tabular}{|c|c|c|c|c|c|}
\hline $\begin{array}{l}\text { 41. My English teachers at high school used to teach for what } \\
\text { purposes to teach English proverbs. }\end{array}$ & 5 & 4 & 3 & 2 & 1 \\
\hline $\begin{array}{l}\text { 42. My English teachers at high school used to refer to the } \\
\text { literary aspects of English proverbs. }\end{array}$ & 5 & 4 & 3 & 2 & 1 \\
\hline $\begin{array}{l}\text { 43. My English teachers at high school used to employ English } \\
\text { proverbs in grammar teaching. }\end{array}$ & 5 & 4 & 3 & 2 & 1 \\
\hline $\begin{array}{l}\text { 44. My English teachers at high school used to employ English } \\
\text { proverbs in vocabulary teaching. }\end{array}$ & 5 & 4 & 3 & 2 & 1 \\
\hline $\begin{array}{l}\text { 45. My English teachers at high school used to employ English } \\
\text { proverbs in pronunciation teaching. }\end{array}$ & 5 & 4 & 3 & 2 & 1 \\
\hline $\begin{array}{l}\text { 46. My English teachers at high school used to employ English } \\
\text { proverbs in the teaching of reading skill. }\end{array}$ & 5 & 4 & 3 & 2 & 1 \\
\hline $\begin{array}{l}\text { 47. My English teachers at high school used to employ English } \\
\text { proverbs in the teaching of listening skill. }\end{array}$ & 5 & 4 & 3 & 2 & 1 \\
\hline $\begin{array}{l}\text { 48. My English teachers at high school used to employ English } \\
\text { proverbs in the teaching of speaking skill. }\end{array}$ & 5 & 4 & 3 & 2 & 1 \\
\hline $\begin{array}{l}\text { 49. My English teachers at high school used to employ English } \\
\text { proverbs in the teaching of writing skill. }\end{array}$ & 5 & 4 & 3 & 2 & 1 \\
\hline $\begin{array}{l}\text { 50. My English teachers at high school used to employ English } \\
\text { proverbs in culture teaching. }\end{array}$ & 5 & 4 & 3 & 2 & 1 \\
\hline $\begin{array}{l}\text { 51. My English teachers at high school used to teach English } \\
\text { proverbs in comparison with Turkish proverbs. }\end{array}$ & 5 & 4 & 3 & 2 & 1 \\
\hline $\begin{array}{l}\text { 52. My English teachers at high school used to allocate special } \\
\text { time for the teaching of English proverbs. }\end{array}$ & 5 & 4 & 3 & 2 & 1 \\
\hline $\begin{array}{l}\text { 53. My English teachers at high school used to complete and } \\
\text { make the parts that they found to be insufficient regarding } \\
\text { proverb teaching in coursebooks more effective and } \\
\text { meaningful. }\end{array}$ & 5 & 4 & 3 & 2 & 1 \\
\hline $\begin{array}{l}\text { 54. I learnt most of the English proverbs not from the } \\
\text { coursebooks we used but only from my teachers at high } \\
\text { school. }\end{array}$ & 5 & 4 & 3 & 2 & 1 \\
\hline $\begin{array}{l}\text { 55. I still use the proverbs I learned from my teachers in } \\
\text { English classes at high school in communication. }\end{array}$ & 5 & 4 & 3 & 2 & 1 \\
\hline $\begin{array}{l}\text { TEACHING OF ENGLISH PROVERBS BY YOUR } \\
\text { ENGLISHCOURSEBOOKS AT HIGH SCHOOL }\end{array}$ & 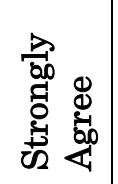 & 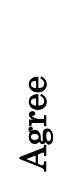 & 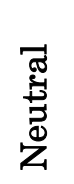 & 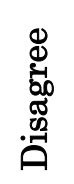 & 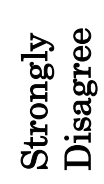 \\
\hline $\begin{array}{l}\text { 56. I learned most of the proverbs I know from the coursebooks } \\
\text { I studied at high school. }\end{array}$ & 5 & 4 & 3 & 2 & 1 \\
\hline $\begin{array}{l}\text { 57. The coursebooks we studied at high school used to dwell on } \\
\text { English proverbs sufficiently. }\end{array}$ & 5 & 4 & 3 & 2 & 1 \\
\hline $\begin{array}{l}\text { 58. The coursebooks we studied at high school used to dwell on } \\
\text { English proverbs sufficiently but my teachers were } \\
\text { skipping the parts related to proverbs. }\end{array}$ & 5 & 4 & 3 & 2 & 1 \\
\hline $\begin{array}{l}\text { 59. The coursebooks we studied at high school used to refer to } \\
\text { English proverbs as effective communication strategies. }\end{array}$ & 5 & 4 & 3 & 2 & 1 \\
\hline
\end{tabular}


60. The coursebooks we studied at high school used to dwell on the structures of English proverbs.

61. The coursebooks we studied at high school used to dwell on the semantic aspects of English proverbs.

62. The coursebooks we studied at high school used to refer to the literary aspects of English proverbs.

63. The coursebooks we studied at high school used to teach in what situations to use English proverbs.

64. The coursebooks we studied at high school used to teach for what purposes to use English proverbs.

65. The coursebooks we studied at high school most often presented English proverbs as a list.

66. The coursebooks we studied at high school used to teach English proverbs in texts.

67. The coursebooks we studied at high school used to present English proverbs in context by means of materials from real life (e.g., cartoons, advertisements, newspaper articles, songs etc.).

68. The coursebooks we studied at high school included activities for the purpose of teaching English proverbs and reinforcing the knowledge of proverbs.

69. The coursebooks we studied at high school used to employ English proverbs in grammar teaching.

70. The coursebooks we studied at high school used to employ English proverbs in vocabulary teaching.

71. The coursebooks we studied at high school used to employ English proverbs in pronunciation teaching.

72. The coursebooks we studied at high school used to employ English proverbs in the teaching of listening skill.

73. The coursebooks we studied at high school used to employ English proverbs in the teaching of reading skill.

74. The coursebooks we studied at high school used to employ English proverbs in the teaching of writing skill.

75. The coursebooks we studied at high school used to employ English proverbs in the teaching of speaking skill.

76. The coursebooks we studied at high school used to employ English proverbs in culture teaching.

77. The coursebooks we studied at high school used to encourage us to compare the English proverbs they presented with the ones in our culture.

\begin{tabular}{|c|c|c|c|c|}
\hline 5 & 4 & 3 & 2 & 1 \\
\hline 5 & 4 & 3 & 2 & 1 \\
\hline 5 & 4 & 3 & 2 & 1 \\
\hline 5 & 4 & 3 & 2 & 1 \\
\hline 5 & 4 & 3 & 2 & 1 \\
\hline 5 & 4 & 3 & 2 & 1 \\
\hline 5 & 4 & 3 & 2 & 1 \\
\hline 5 & 4 & 3 & 2 & 1 \\
\hline 5 & 4 & 3 & 2 & 1 \\
\hline 5 & 4 & 3 & 2 & 1 \\
\hline 5 & 4 & 3 & 2 & 1 \\
\hline 5 & 4 & 3 & 2 & 1 \\
\hline 5 & 4 & 3 & 2 & 1 \\
\hline 5 & 4 & 3 & 2 & 1 \\
\hline 5 & 4 & 3 & 2 & 1 \\
\hline 5 & 4 & 3 & 2 & 1 \\
\hline 5 & 4 & 3 & 2 & 1 \\
\hline 5 & 4 & 3 & 2 & 1 \\
\hline
\end{tabular}

If there is extra information regarding your experience of learning English proverbs at high school, please specify them here: 


\section{Appendix B. Features in the Participants' Proverb Definitions}

\begin{tabular}{|c|c|c|c|c|c|}
\hline \multicolumn{2}{|c|}{$\begin{array}{l}\text { Categories: } \\
\text { Proverbs are... }\end{array}$} & $\begin{array}{l}\text { English Translations } \\
\text { of the Key words }\end{array}$ & $\overline{\mathbf{N}}$ & $\begin{array}{l}\text { Total } \\
\mathbf{N}\end{array}$ & $\%$ \\
\hline \multirow{23}{*}{ 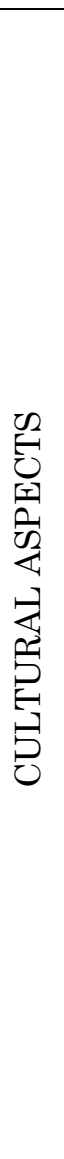 } & \multirow{8}{*}{$\begin{array}{l}\text { From old times/ } \\
\text { traditionality }\end{array}$} & in the old days & 8 & \multirow[t]{8}{*}{87} & \multirow[t]{8}{*}{55.4} \\
\hline & & beforetime & 4 & & \\
\hline & & in the past & 41 & & \\
\hline & & old & 2 & & \\
\hline & & from the past & 3 & & \\
\hline & & for years & 3 & & \\
\hline & & has survived till today & 21 & & \\
\hline & & has come to this day & 5 & & \\
\hline & \multirow[t]{2}{*}{ Anonymous } & anonymous & 10 & \multirow[t]{2}{*}{35} & \multirow[t]{2}{*}{22.3} \\
\hline & & unknown originator & 25 & & \\
\hline & \multirow{6}{*}{$\begin{array}{l}\text { Experience- } \\
\text { based }\end{array}$} & experience & 5 & \multirow[t]{6}{*}{32} & \multirow[t]{6}{*}{20.4} \\
\hline & & experience & 12 & & \\
\hline & & event & 3 & & \\
\hline & & situation & 7 & & \\
\hline & & experience + event & 3 & & \\
\hline & & event + situation & 2 & & \\
\hline & \multirow{3}{*}{$\begin{array}{l}\text { Ancestors' } \\
\text { words }\end{array}$} & ancestors & 2 & \multirow[t]{3}{*}{23} & \multirow[t]{3}{*}{14.6} \\
\hline & & ancestors & 18 & & \\
\hline & & the elderly & 3 & & \\
\hline & \multirow[t]{3}{*}{ Oral tradition } & from mouth to mouth & 1 & \multirow[t]{3}{*}{8} & \multirow[t]{3}{*}{5.1} \\
\hline & & $\begin{array}{l}\text { from generation to } \\
\text { generation }\end{array}$ & 5 & & \\
\hline & & word of mouth & 2 & & \\
\hline & Culture & culture & 8 & 8 & 5.1 \\
\hline \multirow{9}{*}{ 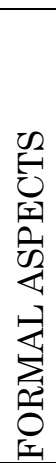 } & \multirow[t]{5}{*}{ Fixed } & fixed & 38 & \multirow[t]{5}{*}{46} & \multirow[t]{5}{*}{29.3} \\
\hline & & can't be changed + fixed & 5 & & \\
\hline & & can't be changed & 1 & & \\
\hline & & cliché & 1 & & \\
\hline & & conventional & 1 & & \\
\hline & \multirow[t]{3}{*}{ Short } & short sayings & 6 & \multirow[t]{3}{*}{27} & \multirow[t]{3}{*}{17.2} \\
\hline & & pithy sayings & 17 & & \\
\hline & & short + pithy sayings & 4 & & \\
\hline & Memorable & memorable & 3 & 3 & 1.9 \\
\hline & \multirow{10}{*}{$\begin{array}{l}\text { Guiding/ } \\
\text { Didactic }\end{array}$} & lesson & 6 & 27 & 17.2 \\
\hline & & lesson + advice & 1 & & \\
\hline$\underline{\mathscr{L}}$ & & lesson + advice & 1 & & \\
\hline 0 & & lesson + didactic & 1 & & \\
\hline$\ddot{\Omega}$ & & lesson + message & 1 & & \\
\hline$\sum_{0}^{2}$ & & advice & 3 & & \\
\hline 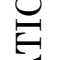 & & advice & 8 & & \\
\hline 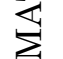 & & advice & 1 & & \\
\hline 岁 & & educating & 1 & & \\
\hline 在 & & guiding & 1 & & \\
\hline
\end{tabular}




\begin{tabular}{|c|c|c|c|c|c|}
\hline & & moral & 2 & & \\
\hline & & message & 1 & & \\
\hline & $\begin{array}{l}\text { Thought- } \\
\text { provoking }\end{array}$ & thought-provoking & 6 & 6 & 3.8 \\
\hline & Ironic & sarcastic & 1 & 2 & 1.3 \\
\hline & & irony & 1 & & \\
\hline & Humorous & funny & 1 & 2 & 1.3 \\
\hline & & entertaining & 1 & & \\
\hline & Metaphorical & metaphorical & 26 & 26 & 16.6 \\
\hline 变至 & Rhyming & rhyming & 2 & 2 & 1.3 \\
\hline & Expressions of & traditions & 2 & 10 & 6.4 \\
\hline & traditions, & emotion & 1 & & \\
\hline & $\begin{array}{l}\text { emotions and } \\
\text { thoughts }\end{array}$ & emotion + thought & 2 & & \\
\hline & & thought & 2 & & \\
\hline 其罢 & & idea + thought & 2 & & \\
\hline 东 & & belief & 1 & & \\
\hline 受岂 & Meaningful & meaningful & 8 & 9 & 5.7 \\
\hline
\end{tabular}

\section{Copyrights}

Copyright for this article is retained by the author(s), with first publication rights granted to the Journal. This is an open-access article distributed under the terms and conditions of the Creative Commons Attribution license (CC BY-NC-ND) (http://creativecommons.org/licenses/by-nc-nd/4.0/). 